\title{
Hemşirelerin ve Hemşirelik Öğrencilerinin Fiziksel Değerlendirme Becerilerini Kullanma Durumları: Karşılaştırmalı Bir Çalışma
}

\author{
$\infty$ \\ Nurcan ÇALIŞKAN ${ }^{1}$, Nevin DOĞAN ${ }^{2}$, Banu CiHAN ERDOĞAN ${ }^{3}$, Nefise Cevriye SUCU ÇAKMAK ${ }^{4}$, \\ Atike Nilay KUBLASHVILI ${ }^{5}$, Gülcan EYÜBOĞLU ${ }^{6}$, Evrim EYIKARA ${ }^{7}$
}

\section{öz}

Amaç: $\mathrm{Bu}$ araştırma, hemşirelerin ve hemşirelik öğrencilerinin fiziksel değerlendirme becerilerini kullanma durumlarını belirlemek amacıyla karşılaştırmalı-tanımlayıcı tasarımda gerçekleştirilmiştir. Gereç ve Yöntem: Bu araştırma, Ankara ve Siirt ilinde bulunan iki üniversite hastanesinin yataklı servislerinde çalışan hemşirelerle ( $n=148$ ) ve iki üniversitede öğrenim gören dördüncü sınıf hemşirelik öğrencileriyle $(n=381)$ gerçekleştirilmiştir. Veriler, araştırmacılar tarafından geliştirilen "Tanıtıcı Özellikler Formu" ve "Fiziksel Değerlendirme Beceri Formu" ile Ocak-Haziran 2018 tarihleri arasında toplanmıştır.

Bulgular: Hemşirelerin \%81.8'inin fiziksel değerlendirme becerilerini bilmelerine rağmen $\% 61.5$ 'inin bu becerileri kullandığı, öğrencilerin \%68.5'inin fiziksel değerlendirmeyle ilgili ders aldığı saptanmıştır. Fiziksel değerlendirme becerilerini uygulamadaki en büyük engel olarak hemşirelerin \%98'i yoğun iş yükünü, öğrencilerin \%76.1'i ise öğretim elemanı desteğindeki yetersizliği belirtmiştir. Fiziksel değerlendirme becerileriyle ilgili ders alan öğrencilerin, klinik deneyim süresi 0-9 yıl olan hemşirelerin ve dahili/cerrahi yoğun bakımda çalışan hemşirelerin fiziksel değerlendirme becerilerini istatistiksel olarak anlamlı düzeyde daha fazla kullandıkları saptanmıştı $(p<0.05)$. Hemşirelerin en çok inspeksiyon yöntemini kullandıkları belirlenmiştir $(p<0.05)$.

Sonuç: Hemşirelerin ve öğrencilerin çoğunun fiziksel değerlendirme yöntemlerini bilmesine karşın uygulamada yaygın olarak kullanamadıkları sonucuna ulaşılmışır. Fiziksel değerlendirme becerilerinin daha yaygın kullanılabilmesi için hemşirelik müfredatında fiziksel değerlendirme dersinin zorunlu olması, öğrencilerin bu becerileri kullanmaları için öğretim elemanlarının daha fazla destek vermesi, hemşirelerin iş yüklerinin azaltılması ve hizmet içi eğitimlerde fiziksel değerlendirme yöntemlerine yer verilmesi önerilmektedir.

Anahtar kelimeler: Fiziksel değerlendirme, hemşirelik, hemşirelik öğrencisi

\begin{abstract}
The Use of Physical Examination Skills by Nurses and Nursing Students: A Comparative Study

Aim: This descriptive-comparative research was conducted to determine the use of physical examination skills by nurses and nursing students.

Material and Methods: This study was conducted with nurses ( $n=148$ ) working in the inpatient services of two university hospitals and senior nursing students $(n=381)$ studying at two universities in Ankara and Siirt. The data were collected between January and June 2018 by using "Demographic Characteristics Form" and "Physical Examination Skill Form" developed by the researchers.

Results: Although $81.8 \%$ of the nurses knew about physical examination skills, $61.5 \%$ of them used these skills and $68.5 \%$ of the students took a course on physical examination. $98 \%$ of the nurses stated the intensive workload as the biggest barrier in applying physical examination skills and $76.1 \%$ of the students stated the lack of support from the instructors. Students who took a course on physical examination skills, nurses with 0-9 years of clinical experience, and nurses working in the internal/surgical intensive care unit were found to use physical examination skills statistically higher $(\mathrm{p}<0.05)$. It was determined that the most frequently used method by the nurses was inspection $(p<0.05)$.

Conclusion: It has been concluded that most of the nurses and students know the physical assessment methods but do not use them widely in practice. In order for physical assessment skills to be used more widely, it is recommended that the physical assessment course be compulsory in the nursing curriculum, instructors provide more support for students to use these skills, reduce the workload of nurses, and include physical assessment methods in in-service training.
\end{abstract}

Keywords: Nursing, nursing student, physical examination

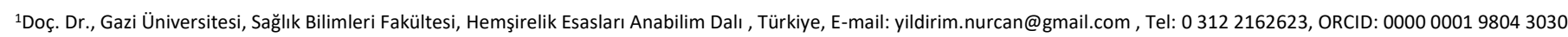
${ }^{2}$ Arş.Gör., Gazi Üniversitesi, Sağlık Bilimleri Fakültesi, Hemşirelik Esasları Anabilim Dalı, Türkiye, E-mail: nevin-blg@hotmail.com , Tel: $03122162623,0 R C I D: 0000$ 0002 44479469

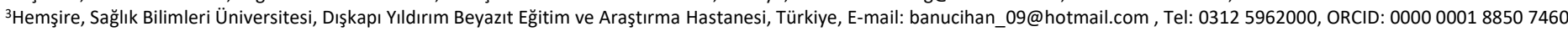

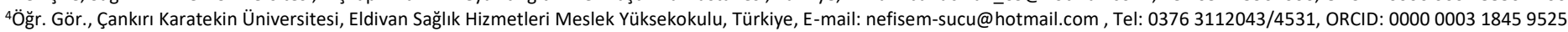
${ }^{5}$ Doktora Öğrencisi, Gazi Üniversitesi, Sağlık Bilimleri Enstitüsü, Türkiye, E-mail: nilkar33@gmail.com, Tel: 0312 2162623, ORCID: 000000024439 5564

${ }^{6}$ Arş.Gör., Gazi Üniversitesi, Sağlık Bilimleri Fakültesi, Hemşirelik Esasları Anabilim Dalı, Türkiye, E-mail: gulcanboke@gmail.com, Tel: 03122162989 , ORCID:0000 0002 5978 3957 ${ }^{7}$ Arş.Gör., Gazi Üniversitesi, Sağlık Bilimleri Fakültesi, Hemşirelik Esasları Anabilim Dalı, Türkiye, E-mail: evrimeyikara@gmail.com, Tel: $03122162623,0 R C I D: 00000003$ 1334 4243 Geliş Tarihi: 13 Kasım 2019, Kabul Tarihi: 2 Haziran 2020

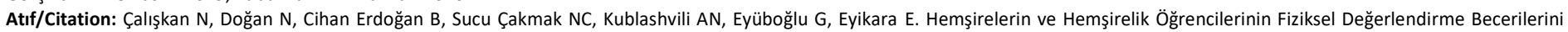
Kullanma Durumları: Karşılaştırmalı Bir Çalışma. Hacettepe Üniversitesi Hemşirelik Fakültesi Dergisi 2020; 7(3): 206-214. DOI: 10.31125/hunhemsire.834028 


\section{Giriş̧}

Günümüzde sağlık bakım sisteminde yaşanan değişimler, nitelikli hemşire yetiştirmeye ilişkin artan talep göz önünde bulundurulduğunda hemşirelerin mesleki anlamda yetkin olmaları gerekmektedir. Bu yetkinlik alanlarından birisi de sağlığın değerlendirilmesidir ${ }^{1}$. Profesyonel hemşirelik rolünün ve bütüncül hemşirelik yaklaşımının önemli bir bileşeni olan sağlığın değerlendirilmesi; sağlık öyküsünün alınması, fiziksel değerlendirme yapılması, sağlık kayıtlarından diğer verilerin elde edilmesi ve saptanan verilerin kaydedilmesi basamaklarını içermektedir ${ }^{2}$. Hemşirelik sürecinin ilk adımı olan sağlığın değerlendirilmesi; evrensel bir yaklaşım olarak kabul edilir ve klinik kararları doğrulayabilmek açısından önemlidir ${ }^{3,4}$.

Sağlığın değerlendirilmesi sürecinin önemli bir basamağını oluşturan fiziksel değerlendirme; doğrudan ortaya çıkan veya inspeksiyon, palpasyon, perküsyon ve oskültasyon gibi yöntemlerden elde edilen verilerin sistematik olarak bir araya getirilmesidir ${ }^{5}$. Hemşireler fiziksel değerlendirme becerilerini kullanarak hastanın mevcut sağlık durumunu belirlemek, hastanın durumundaki olumlu veya olumsuz değişimleri tanımlamak gibi önemli sorumluluklara sahiptir. Dolayısıyla sağlığın değerlendirilmesi ve fiziksel muayene, güvenli ve yetkin hemşirelik bakımı sağlayabilmenin ilk adımıdır ${ }^{6}$. Hemşirelerin fiziksel değerlendirme becerilerini kullanması; subjektif verileri doğrulama, sistematik bakımı kolaylaştırma, hemşire-hasta iletişimini sağlayarak güven ilişkisini güçlendirme, bakımın sürekliliğini sağlama, hemşirenin özerkliğini güçlendirme gibi katkılar sağlamaktadır ${ }^{7-9}$. Buna rağmen literatürde fiziksel değerlendirmenin hemşireler tarafından iş yoğunluğu, zaman yetersizliği, rol belirsizlikleri, diğer sağlık profesyonellerine ve teknolojik araçlara daha çok güvenme, bilgi ve beceri eksikliği, kaynak yetersizliği, fiziksel değerlendirmenin hasta bakım kalitesine önemli bir katkısının olmadığına inanma, özgüven eksikliği gibi nedenlerle göz ardı edilebildiğ $\mathrm{i}^{2,3,10}$ ve bu nedenle hemşirelerin fiziksel değerlendirme becerilerini kullanma sıklığının düşük olduğu saptanmıştır ${ }^{11}$.

Klinik uygulamalarda hemşirelerin yanı sıra hemşirelik öğrencilerinin de fiziksel değerlendirme yapması beklenmektedir. Ancak hemşirelik eğitim programlarında fiziksel değerlendirmenin genellikle seçmeli bir ders olması, öğrencilerde özgüven eksikliği, zaman yetersizliği gibi nedenlerle öğrencilerin de istendik düzeyde fiziksel değerlendirme yapmadıkları belirtilmektedir ${ }^{12,13}$. Giddens ve Eddy (2009) tarafından yapılan araştırmada, klinik uygulamada fiziksel değerlendirme becerilerinin daha çok kullanılabilmesi için hemşirelik eğitim programlarının derinlemesine gözden geçirilmesi gerektiği bildirilmiştir ${ }^{14}$.

Fiziksel değerlendirme hemşirelik uygulamalarının ayrılmaz bir parçası olmasına rağmen, klinik kullanımına ilişkin ülkemizde sınırlı sayıda araştırma bulunmaktadır ve araştırmalar çoğunlukla hemşireler ile yapılmıştır ${ }^{15-17}$. Ülkemizde fiziksel değerlendirmenin hemşireler ve hemşirelik öğrencileri tarafından kullanımını karşılaştıran bir araştırmaya rastlanmamıştır. Gözlemlerimiz, hemşirelik eğitim programlarında öğretilen fiziksel değerlendirme becerilerinin klinik ortamda oldukça sınırlı kullanıldığı yönündedir. Dolayısıyla, fiziksel değerlendirme becerilerinin hemşireler ve hemşirelik öğrencileri tarafından uygulamadaki yansımalarının belirlenmesi ve güncel bilimsel veriler ile karşılaştırılması, teorik eğitimin klinik uygulamaya aktarımını değerlendirmek açısından önemlidir. Araştırma sonucunda elde edilen verilerin hemşirelik eğitim programlarında ders içeriklerinin geliştirilmesine ve hemşirelere konuyla ilgili hizmet içi eğitimlerin geliştirilmesine katkı sağlayacağı düşünülmektedir.

\section{Araştırmanın Amacı}

$\mathrm{Bu}$ araştırma, hemşirelerin ve hemşirelik öğrencilerinin fiziksel değerlendirme becerilerini kullanma durumlarını belirlemek ve iki grubu karşılaştırmak amacıyla yapılmıştır.

\section{GEREÇ ve YÖNTEM}

\section{Araştırmanın Türü}

$\mathrm{Bu}$ araştırma, hemşirelerin ve hemşirelik öğrencilerinin fiziksel değerlendirme becerilerini kullanma durumlarını belirlemek amacıyla karşılaştırmalı-tanımlayıcı türde yapılmıştır.

\section{Araştırma Evren ve Örneklemi}

Bu araştırmanın iki evreni vardır. Birinci evrenini; Türkiye'nin farklı bölgelerinde bulunan iki üniversitenin dördüncü sınıf hemşirelik öğrencileri oluşturmuştur (Ankara $n=293$, Siirt $\mathrm{n}=220$ ). İkinci evrenini ise bu eğitim kurumlarında bulunan öğrencilerin uygulamaya çıktığı hastanelerde çalışan hemşireler oluşturmuştur (Ankara $n=440$, Siirt $n=148$ ). Araştırmada örneklem seçimine gidilmemiştir. Araştırmaya katılmaya gönüllü olan ve veri toplama formunu eksiksiz dolduran, hastanenin tüm yataklı servislerinde çalışan 148 hemşire ve 381 hemşirelik öğrencisi örneklem grubunu oluşturmuştur. Araştırmaya katılım oranı öğrencilerde $\% 74.26$ ve hemşirelerde $\% 25.17$ 'dir.

\section{Veri Toplama Araçları}

Araştırma verileri araştırmacılar tarafından geliştirilen "Tanıtıcı Özellikler Formu" ve "Fiziksel Değerlendirme Beceri Formu" ile toplanmıştır. Hemşirelere uygulanan Tanıtıcı Özellikler Formu; hemşirelerin sosyodemografik özellikleri ve fiziksel değerlendirme becerileriyle ilişkili on sorudan, hemşirelik öğrencilerine uygulanan form ise altı sorudan oluşmuştur.

Fiziksel Değerlendirme Beceri Formu, Giddens (2007) ve Giddens ve Eddy (2009) tarafından oluşturulan ve hemşirelerin en sık kullandıkları fiziksel değerlendirme becerileri temel alınarak araştırmacılar tarafından hazırlanmıştı ${ }^{10,14}$. Bu form, altılı likert tipte ve 29 maddeden oluşmaktadır. Formda yer alan her bir maddeye hemşirelerin ve öğrencilerin 0 ile 5 puan arasında bir işaretleme yapması istenmiştir. Maddeler "Ben bu tekniğin nasıl yapıldığını bilmiyorum (0 puan)", "Ben bu tekniğin nasıl yapılacağını biliyorum fakat benim klinik uygulamamın bir parçası değil (1 puan)", "Nadiren bu tekniği gerçekleştiririm (2 puan)", "Bu tekniği bazen gerçekleştiririm (3 puan)", "Klinik uygulamamda bu tekniği sık sık gerçekleştiririm (4 puan)", "Klinik uygulamamda düzenli olarak bu tekniği gerçekleştiririm (5 puan)" şeklinde puanlandırılmıştır. Formdan alınabilecek en düşük puan 0 , en yüksek puan 145 'tir. Elde edilen puanın artması, fiziksel değerlendirme 
becerilerinin klinik uygulamada kullanım sıklığının arttığını göstermektedir.

\section{Araştırmanın Ön Uygulaması}

Araştırmanın ön uygulaması Aralık 2017'de, Ankara'daki üniversitenin üçüncü sınıfındaki 10 hemşirelik öğrencisi ve üniversiteye bağıı hastanede çalışan 10 klinik hemşiresi ile yapılmıştır. Ön uygulamadan sonra veri toplama formlarında herhangi bir değişiklik yapılmasına gerek duyulmamıştır. Ayrıca ön uygulama sonucunda elde edilen veriler örneklem grubuna dahil edilmemiştir.

\section{Veri Toplama Araçlarının Uygulanması}

Araştırmanın verileri Ocak-Haziran 2018 tarihleri arasında araştırmacılar tarafından toplanmıştır. Hemşirelerin verileri toplanırken ilk olarak klinik sorumlu hemşirelerine ve klinikte çalışan hemşirelere araştırma hakkında bilgi verilmiştir. Araştırmaya katılmayı kabul eden hemşirelere veri toplama formu dağıtılmıştır ve doldurulan formlar mesai saatlerinden sonra teslim alınmıştır. Hemşirelik öğrencilerinin verileri ise öğrencilerin ders saatleri dışında bir zaman diliminde ve sınıf ortamında toplanmıştır. Her bir formun doldurulması yaklaşık 10 dakika sürmüştür.

\section{Verilerin Değerlendirilmesi}

Araştırmanın verileri Statistical Packages for Social Science (SPSS 21.0) paket programı ile sayısallaştırılmıştır. Tanımlayıcı istatistiklerde sayısal veriler ortalama ve standart sapma değerleriyle; kategorik yapıdaki veriler sayı ve yüzde ile ifade edilmiştir. Normal dağılım gösteren verilerin değerlendirmesinde t-testi, normal dağılım göstermeyen verilerin karşılaştırılmasında ise Kruskal-Wallis varyans analizi kullanılmıştır. íki grup ortalamalarının karşılaştırmasında ki-kare testi kullanmıştır. İstatistiksel anlamlılık düzeyi olarak $p<0.05$ kabul edilmiştir.

\section{Araştırmanın Etik Boyutu}

Araştırmanın uygulanmasına başlamadan önce Gazi Üniversitesi Etik Komisyonu'ndan etik komisyon izni (Karar No: E.147531, Karar Tarihi: 17.10.2017) ve kurumlardan yazılı izin alınmıştır. Araştırmaya katılan öğrencilerin ve hemşirelerin ise yazılı onamları alınmıştır.

\section{Araştırmanın Sınırlılıkları}

Araştırmaya katılım oranının hemşireler için \%25.17 olması araştırmanın sınırlılığıdır. Hemşirelerin araştırmaya katılımının düşük olmasının başlıca nedenleri, iş yüklerinin fazla olması ve araştırmaya katılma konusunda çoğunlukla isteksiz davranmalarıdır.

\section{BULGULAR}

Araştırmadan elde edilen bulgulara göre; hemşirelerin yaş ortalaması 32.63 \pm 7.21 , \%89.9'u kadın, \%33.8'i cerrahi kliniklerinde görev yapmakta, \%33.8'i 5-9 yıldır çalışmaktadır. Hemşirelerin $\% 81.8^{\prime}$ inin fiziksel değerlendirme becerilerini bildiği, \%58.1'nin fiziksel değerlendirme becerilerini temel hemşirelik eğitiminde öğrendiği, \%61.5'inin fiziksel değerlendirme becerilerini klinik uygulamalarda kullandığı belirlenmiştir. Hemşireler fiziksel değerlendirme becerilerini uygulamada karşılaştıkları başlıca engelleri; iş yükü (\%98), fiziksel değerlendirme için yeterli zaman olmaması (\%66.9), yeterli bilgi ve beceriye sahip olmama (\%64.9), fiziksel değerlendirmenin hemşirenin görevi olarak düşünülmemesi (\%52) olarak belirtmişlerdir (Tablo 1).

Tablo 1. Hemşirelerin Tanıtıcı Özellikleri

\begin{tabular}{|c|c|c|}
\hline \multicolumn{3}{|l|}{ Tanıtıcı özellikler } \\
\hline \multirow{2}{*}{$\begin{array}{l}\text { Yaş } \\
\text { Cinsiyet }\end{array}$} & \multicolumn{2}{|c|}{$\begin{array}{l}\mathrm{X} \pm \mathrm{SS}=32.63 \pm 7.21(\min : 20 \\
\mathrm{maks}: 55)\end{array}$} \\
\hline & $\mathbf{n}$ & $\%$ \\
\hline Kadın & 133 & 89.9 \\
\hline Erkek & 15 & 10.1 \\
\hline \multicolumn{3}{|l|}{ Eğitim durumu } \\
\hline Lise & 27 & 18.2 \\
\hline Önlisans & 22 & 14.9 \\
\hline Lisans & 91 & 61.5 \\
\hline Lisansüstü & 8 & 5.4 \\
\hline \multicolumn{3}{|c|}{ Görev yapılan hastanenin yer aldığı il } \\
\hline Ankara & 101 & 68.2 \\
\hline Siirt & 47 & 31.8 \\
\hline \multicolumn{3}{|l|}{ Görev yapılan birim } \\
\hline Cerrahi klinik & 50 & 33.8 \\
\hline Dahili klinik & 43 & 29.1 \\
\hline Yoğun bakım & 16 & 10.8 \\
\hline Diğer* & 39 & 26.4 \\
\hline \multicolumn{3}{|l|}{ Klinik deneyim süresi } \\
\hline $0-4$ yıl & 41 & 27.7 \\
\hline $5-9 \mathrm{yıl}$ & 50 & 33.8 \\
\hline 10-19 yıl & 45 & 30.4 \\
\hline 20 yıl ve üzeri & 12 & 8.1 \\
\hline \multicolumn{3}{|c|}{ FD** becerilerini uygulamayı bilme durumu } \\
\hline Bilen & 121 & 81.8 \\
\hline Bilmeyen & 27 & 18.2 \\
\hline \multicolumn{3}{|c|}{ FD becerilerini öğrenme kaynağı } \\
\hline $\begin{array}{l}\text { Temel hemşirelik } \\
\text { eğitimi }\end{array}$ & 86 & 58.1 \\
\hline Hizmet içi eğitim & 22 & 14.9 \\
\hline Lisansüstü eğitim & 5 & 3.4 \\
\hline Kurs, kongre & 4 & 2.7 \\
\hline Diğer*** & 5 & 3.4 \\
\hline \multicolumn{3}{|c|}{ FD becerilerini kullanma durumu } \\
\hline Kullanan & 91 & 61.5 \\
\hline Kullanmayan & 57 & 38.5 \\
\hline
\end{tabular}


Tablo 1. Hemşirelerin Tanıtıcı Özellikleri (devamı)

\begin{tabular}{|c|c|c|}
\hline \multicolumn{3}{|c|}{$\begin{array}{l}\text { Hemşirelerin FD becerilerini uygulamada karşılaştığ| } \\
\text { engeller**** }\end{array}$} \\
\hline İş yükü & 145 & 98.0 \\
\hline $\begin{array}{l}\text { FD yapmak için } \\
\text { yeterli zaman } \\
\text { olmaması }\end{array}$ & 99 & 66.9 \\
\hline $\begin{array}{l}\text { Yeterli bilgiye ve } \\
\text { beceriye sahip } \\
\text { olmama }\end{array}$ & 96 & 64.9 \\
\hline $\begin{array}{l}\text { Hemşirenin görevi } \\
\text { olarak } \\
\text { düşünülmemesi }\end{array}$ & 77 & 52.0 \\
\hline $\begin{array}{l}\text { Kendine güven } \\
\text { eksikliği }\end{array}$ & 71 & 48.0 \\
\hline $\begin{array}{l}\text { İşini iyi yapmak için } \\
\text { gerekli } \\
\text { görülmemesi }\end{array}$ & 71 & 48.0 \\
\hline $\begin{array}{l}\text { Hastaların FD } \\
\text { yapılmasını kabul } \\
\text { etmemesi }\end{array}$ & 71 & 48.0 \\
\hline $\begin{array}{l}\text { Hekimlerin } \\
\text { desteklememesi }\end{array}$ & 71 & 48.0 \\
\hline $\begin{array}{l}\text { Meslektaşların FD } \\
\text { yapmayı } \\
\text { desteklememesi }\end{array}$ & 67 & 45.3 \\
\hline $\begin{array}{l}\text { Yöneticilerin } \\
\text { desteklememesi }\end{array}$ & 66 & 44.6 \\
\hline $\begin{array}{l}\text { FD'nin yetişkin } \\
\text { hastada yanlış } \\
\text { algıllanması }\end{array}$ & 1 & 0.7 \\
\hline
\end{tabular}

*Acil servis, Pediatri, Psikiyatri

**FD: Fiziksel değerlendirme

***internet

***Birden fazla seçenek işaretlenmiştir.

Araştırmaya katılan öğrencilerin yaş ortalaması $22.56 \pm 1.54$ ve $\% 72.4^{\prime}$ ü kadındır. Öğrencilerin $\% 68.5^{\prime} i$ fiziksel değerlendirmeyle ilgili ders aldığını, \%66.1'i fiziksel değerlendirme becerilerini klinik uygulamalarda kullandığını belirtmiştir. Öğrenciler fiziksel değerlendirme becerilerini uygulamada karşılaştıkları başlıca engelleri; öğretim elemanının öğrencilerin fiziksel değerlendirme becerilerini uygulamasını desteklememesi (\%76.1), hemşirelik eğitim programlarında fiziksel değerlendirme becerilerini içeren dersin bulunmaması (\%62.7), hastaların fiziksel değerlendirme yapmayı kabul etmemesi (\%54.1), hemşirelik eğitim programlarında fiziksel değerlendirme becerilerini içeren dersin seçmeli olması (\%53.5) olarak belirtmiştir (Tablo 2).

Tablo 2. Öğrencilerin Tanıtıcı Özellikleri

\begin{tabular}{|c|c|c|}
\hline \multicolumn{3}{|c|}{ Tanıtıcı özellikler } \\
\hline \multirow{2}{*}{$\begin{array}{l}\text { Yaş } \\
\text { Cinsiyet }\end{array}$} & \multicolumn{2}{|c|}{$\begin{array}{l}X \pm S S=22.56 \pm 1.54 \\
(\min : 20, \text { maks:32) }\end{array}$} \\
\hline & $\mathbf{n}$ & $\%$ \\
\hline Kadın & 276 & 72.4 \\
\hline Erkek & 105 & 27.6 \\
\hline \multicolumn{3}{|c|}{ Öğrencisi oldukları üniversitenin bulunduğu il } \\
\hline Ankara & 230 & 60.4 \\
\hline Siirt & 151 & 39.6 \\
\hline
\end{tabular}

Tablo 2. Öğrencilerin Tanıtıcı Özellikleri (devamı)

\begin{tabular}{|c|c|c|}
\hline \multicolumn{3}{|c|}{ FD* becerileri konusunda daha önce ders alma durumu } \\
\hline Ders alan & 261 & 68.5 \\
\hline Ders almayan & 120 & 31.5 \\
\hline \multicolumn{3}{|l|}{ FD becerilerini kullanma durumu } \\
\hline Kullanan & 252 & 66.1 \\
\hline Kullanmayan & 129 & 33.9 \\
\hline \multicolumn{3}{|c|}{ Öğrencilerin FD becerilerini uygulamada karşılaştığı engeller** } \\
\hline $\begin{array}{l}\text { Öğretim elemanının öğrencileri } \\
\text { desteklememesi }\end{array}$ & 290 & 76.1 \\
\hline $\begin{array}{l}\text { Hemşirelik eğitim programlarında } \\
\text { FD becerilerini içeren ders } \\
\text { bulunmaması }\end{array}$ & 239 & 62.7 \\
\hline $\begin{array}{l}\text { Hastaların FD yapılmasını kabul } \\
\text { etmemesi }\end{array}$ & 206 & 54.1 \\
\hline $\begin{array}{l}\text { Hemşirelik eğitim programlarında } \\
\text { FD becerilerini içeren dersin } \\
\text { seçmeli olması }\end{array}$ & 204 & 53.5 \\
\hline $\begin{array}{l}\text { Hekimlerin öğrencileri } \\
\text { desteklememesi }\end{array}$ & 195 & 51.2 \\
\hline $\begin{array}{l}\text { Öğrenci hemşirenin görevi olarak } \\
\text { düşünülmemesi }\end{array}$ & 174 & 45.7 \\
\hline Kendine güven eksikliği & 165 & 43.3 \\
\hline Yeterli bilgi ve becerinin olmaması & 161 & 42.3 \\
\hline $\begin{array}{l}\text { Hemşirelerin öğrencileri } \\
\text { desteklememesi }\end{array}$ & 151 & 39.6 \\
\hline
\end{tabular}

*FD: Fiziksel değerlendirme

**Birden fazla seçenek işaretlenmiştir.

Tablo 3'te öğrencilerin fiziksel değerlendirme becerilerini kullanma puan ortalamaları ile istatistiksel analizlerde anlamlı olan demografik özelliklerine göre dağılımı verilmiştir. Ankara'da öğrenim gören öğrencilerin fiziksel değerlendirme becerilerini kullanmaya ilişkin puan ortalamaları, diğer üniversitenin öğrencilerine göre istatistiksel olarak anlamlıdır. Fiziksel değerlendirme dersini alan öğrencilerin bu becerileri kullanma puan ortalamaları arasındaki fark, dersi almayan öğrencilere göre istatistiksel olarak anlamlıdır $(p<0.05)$ (Tablo 3$)$. Öğrencilerin yaş ve cinsiyete göre fiziksel değerlendirme becerilerini uygulama puanları istatistiksel olarak anlamlı bulunmamıştır $(p>0.05)$.

Tablo 4'te hemşirelerin fiziksel değerlendirme becerilerini kullanma puan ortalamaları ile istatistiksel analizlerde anlamlı olan demografik özelliklerine göre dağılımı verilmiştir. Hemşirelerden eğitim seviyesi lisans ve lisansüstü olanların, klinik deneyim süresi 0-4 yıl / 5-9 yıl olanların, dahili, cerrahi ve yoğun bakım kliniklerinde çalışan hemşirelerin fiziksel değerlendirme becerilerini uygulama puanları istatistiksel olarak anlamlı düzeyde yüksektir $(p<0.05)$ (Tablo 4). Hemşirelerin yaş ve cinsiyete göre fiziksel değerlendirme becerilerini uygulama puanları istatistiksel olarak anlamlı bulunmamıştır ( $p>0.05$ ). 
Tablo 3. Öğrencilerin Fiziksel Değerlendirme Becerilerini Kullanma Puan Ortalamaları ve Bazı Demografik Özelliklerine Göre Dağıımı

\begin{tabular}{|c|c|c|c|c|}
\hline Fiziksel Değerlendirme Becerileri & $\begin{array}{c}\text { Yanitların Genel } \\
\bar{X} \text { (SS) }\end{array}$ & $0-1$ yanıtının \% & Okuduğu üniversite & $\begin{array}{l}\text { FD dersini alma } \\
\text { durumu }\end{array}$ \\
\hline Hareket ve duyu yönünden yüz değerlendirilmesi & $2.71(1.66)$ & 27.6 & $*$ & $* * \mathrm{~b}$ \\
\hline Göz değerlendirmesi & $2.65(1.52)$ & 25.2 & $*$ & $* * \mathrm{~b}$ \\
\hline Eksternal gözlerin inspeksiyonu & $1.99(1.61)$ & 40.9 & $*$ & $* * \mathrm{~b}$ \\
\hline Oral kaviteninin inspeksiyonu & $2.14(1.65)$ & 39.1 & $*$ & $* * \mathrm{~b}$ \\
\hline Eforlu nefes değerlendirilmesi & $2.26(1.62)$ & 34.4 & $*$ & $* * \mathrm{~b}$ \\
\hline Konuşma değerlendirilmesi & $3.03(1.60)$ & 21.3 & $*$ & $* * \mathrm{~b}$ \\
\hline Göğüs şeklinin inspeksiyonu & $2.53(1.57)$ & 28.1 & $*$ & $* * \mathrm{~b}$ \\
\hline Omurga inspeksiyonu & $2.16(1.49)$ & 34.9 & $*$ & $* * \mathrm{~b}$ \\
\hline Meme inspeksiyonu & $2.07(1.44)$ & 37.5 & $*$ & $* * \mathrm{~b}$ \\
\hline Boyut ve simetri açısından kas, ekstremite inspeksiyonu & $2.22(1.55)$ & 34.6 & $*$ & $* * \mathrm{~b}$ \\
\hline Ten rengi ve kıl büyümesi için ekstremite inspeksiyonu & $2.10(1.54)$ & 37.3 & * a & $* * \mathrm{~b}$ \\
\hline Hassasiyet yönünden ekstremite palpasyonu & $2.42(1.53)$ & 28.1 & $*$ & $* * \mathrm{~b}$ \\
\hline Ödem yönünden ekstremite inspeksiyonu, palpasyonu & $2.96(1.64)$ & 21.8 & $*$ & $* * \mathrm{~b}$ \\
\hline Ekstremitelerin ısınının palpasyonu & $2.73(1.68)$ & 26.0 & $*$ & $* * \mathrm{~b}$ \\
\hline Kas gücü değerlendirilmesi & $2.67(1.65)$ & 26.8 & $*$ & $* * \mathrm{~b}$ \\
\hline Eklem hareketlerinin gözlenmesi & $2.77(1.60)$ & 22.8 & $*$ & $* * \mathrm{~b}$ \\
\hline Kalbin seslerinin oskültasyonu & $2.62(1.58)$ & 26.2 & $*$ & $* * \mathrm{~b}$ \\
\hline Akciğer seslerinin oskültasyonu & $2.45(1.61)$ & 30.4 & $*$ & $* * \mathrm{~b}$ \\
\hline Abdomen inspeksiyonu & $2.37(1.62)$ & 33.9 & $*$ & $* * \mathrm{~b}$ \\
\hline Hassasiyet, distansiyon yönünden abdomen palpasyonu & $2.29(1.56)$ & 35.2 & $*$ & $* * \mathrm{~b}$ \\
\hline Bağırsak seslerinin abdomenden oskültasyonu & $2.35(1.61)$ & 32.3 & * & $* * \mathrm{~b}$ \\
\hline Kapiller dolum palpasyonu ve inspeksiyonu & $2.33(1.71)$ & 35.4 & $*$ & $* * \mathrm{~b}$ \\
\hline Dolaşım için distal atımların palpasyonu & $2.17(1.68)$ & 39.9 & $*$ & $* * \mathrm{~b}$ \\
\hline Gaitanın incelenmesi ve inspeksiyonu & $1.64(1.46)$ & 52.5 & $*$ & $* * \mathrm{~b}$ \\
\hline Genel cilt renginin inspeksiyonu & $2.94(1.61)$ & 21.3 & $*$ & $* * \mathrm{~b}$ \\
\hline Deri lezyonlarının inspeksiyonu & $2.88(1.61)$ & 22.8 & * & $* * \mathrm{~b}$ \\
\hline Yaraların inspeksiyonu & $2.86(1.62)$ & 23.4 & $*$ & $* * \mathrm{~b}$ \\
\hline Glasgow koma ölçeği değerlendirilmesi & $2.75(1.75)$ & 27.3 & $*$ & $* * \mathrm{~b}$ \\
\hline Yürüyüşün değerlendirilmesi & $3.19(1.63)$ & 18.1 & $*$ & $* * \mathrm{~b}$ \\
\hline
\end{tabular}

0-1 yanıtın yüzdesi= "Ben bu tekniğin nasıl yapıldığııı bilmiyorum" ve "Ben bu tekniğin nasıl yapılacağııı biliyorum fakat benim klinik uygulamamın bir parçası deği"

$\left.{ }^{*}\right)$ t testi $p<0.05 \quad$ (a) Ankara'daki unversitede oğrenim goren ogrencilerin lehine anlamlı 
Tablo 4. Hemşirelerin Fiziksel Değerlendirme Becerilerini Kullanma Puan Ortalamaları ve Bazı Demografik Özelliklerine Göre Dağılımı

\begin{tabular}{|c|c|c|c|c|c|}
\hline Fiziksel Değerlendirme Becerileri & $\begin{array}{l}\text { Yanitların Genel } \\
\text { X (SS) }\end{array}$ & $0-1$ yanitının \% & Eğitim seviyesi & $\begin{array}{l}\text { Klinik deneyim } \\
\text { süresi }\end{array}$ & Çalıştığı birim \\
\hline Hareket ve duyu yönünden yüz değerlendirilmesi & $2.87(1.74)$ & 31.1 & & & $* * * \mathrm{c} 1$ \\
\hline Göz değerlendirmesi & 2.64 (1.69) & 29.1 & & & $* * * \mathrm{c} 1$ \\
\hline Eksternal gözlerin inspeksiyonu & $1.86(1.67)$ & 49.3 & *a1 & & $* * * \mathrm{c2}$ \\
\hline Oral kaviteninin inspeksiyonu & $2.11(1.66)$ & 38.5 & * a 2 & & \\
\hline Eforlu nefes değerlendirilmesi & $2.39(1.81)$ & 41.9 & & & $* * * \mathrm{c} 1$ \\
\hline Konuşma değerlendirilmesi & $2.72(1.68)$ & 29.7 & & & ****c2 \\
\hline Göğüs şeklinin inspeksiyonu & $2.26(1.68)$ & 40.5 & & & \\
\hline Omurga inspeksiyonu & $1.70(1.55)$ & 58.1 & & & \\
\hline Meme inspeksiyonu & $1.64(1.48)$ & 59.5 & & & \\
\hline Boyutu ve simetri durumu açısından kas,ekstremite inspeksiyonu & $1.69(1.55)$ & 56.1 & & & $* * * \mathrm{c2}$ \\
\hline Ten rengi ve kıl büyümesi için ekstremitelerin inspeksiyonu & $2.00(1.69)$ & 46.6 & & & $* * * \mathrm{c2}$ \\
\hline Hassasiyet yönünden ekstremite palpasyonu & $2.70(1.65)$ & 27.7 & & & ***a1 \\
\hline Ödem yönünden ekstremite inspeksiyonu ve palpasyonu & $2.99(1.51)$ & 19.6 & *аз аз & **b & *** c1 \\
\hline Ekstremitelerin Isınının palpasyonu & $2.99(1.60)$ & 22.3 & & & $* * *$ с2 \\
\hline Kas gücü değerlendirilmesi & $2.62(1.59)$ & 29.1 & $* \mathrm{a}_{4}$ & & $* * * \mathrm{c2}$ \\
\hline Eklem hareketlerinin gözlenmesi & $2.29(1.65)$ & 36.5 & & & \\
\hline Kalbin seslerinin oskültasyonu & $1.78(1.68)$ & 52.0 & & & \\
\hline Akciğer seslerinin oskültasyonu & $1.84(1.60)$ & 50.0 & & & $* * * \mathrm{c} 1$ \\
\hline Abdomen inspeksiyonu & $1.93(1.51)$ & 43.9 & & & \\
\hline Hassasiyet, distansiyon yönünden abdomen palpasyonu & $1.82(1.52)$ & 48.6 & & & $* * * \mathrm{c3}$ \\
\hline Bağırsak seslerinin abdomenden oskültasyonu & 1.89 (1.59) & 47.3 & & & \\
\hline Kapiller dolum palpasyonu ve inspeksiyonu & $2.05(1.74)$ & 48.0 & & & \\
\hline Dolaşım için distal atımların palpasyonu & $2.36(1.75)$ & 37.2 & & & \\
\hline Gaitanın incelenmesi ve inspeksiyonu & $1.98(1.66)$ & 46.6 & & & $* * *$ с2 \\
\hline Genel cilt renginin inspeksiyonu & $2.95(1.65)$ & 23.0 & & & $* * * \mathrm{c} 2$ \\
\hline Deri lezyonlarının inspeksiyonu & $2.84(1.65)$ & 24.3 & & & $* * * \mathrm{c2}$ \\
\hline Yaraların inspeksiyonu & $2.84(1.70)$ & 27.0 & & & $* * * \mathrm{c} 2$ \\
\hline Glasgow koma ölçeği değerlendirilmesi & $3.05(1.83)$ & 29.1 & & & $* * * \mathrm{c2}$ \\
\hline Yürüyüşün değerlendirilmesi & $3.35(1.61)$ & 20.9 & & & $* * * \mathrm{c2}$ \\
\hline
\end{tabular}

0-1 yanıtın yüzdesi= "Ben bu tekniğin nasıl yapıldığııı bilmiyorum" ve "Ben bu tekniğin nasıl yapılacağıııı biliyorum fakat benim klinik uygulamamın bir parçası değil"

(*) KW testi p<0.05 (a1) Eğitim durumu ön lisans olanlara göre lise ve lisansüstü olanların lehine anlamlı,

(a2) Eğitim durumu lise, ön lisans ve lisans olanlara göre lisansüstü olanların lehine anlamlı

(a3) Eğitim durumu ön lisans olanlara göre lisansüstü olanların lehine anlamlı

(**) KW Egitim durumu on lisans olanlara gore lise, lisans ve lisansütu olanların lehine anlamlı

${ }^{* * *}$ KW KW testi $p<0.05$ (b) Klinik deneyim süresi $10-19$ yil olanlara göre $0-4$ yil ve $5-9$ yll olanların lehine anlamlı

(c2) Diğer birimlerde çalıșanlara göre dahili, cerrahi ve yoğun bakım birimlerde çalışanların lehine anlamı

(c3) Diğer birimlerde çalışanlara göre dahili ve yoğun bakımda çalışanların lehine anlamlı 
Tablolarda yer almamakla birlikte, öğrencilerin ve hemşirelerin fiziksel değerlendirme becerilerine verdikleri yanıtlar karşılaştırıldığında; hemşirelerin hareket ve duyu yönünden yüz değerlendirmesi $\left(\chi^{2}=30,888 ; p=0,000\right)$, eforlu nefes değerlendirmesi $(\chi 2=25,309 ; p=0.000)$, ekstremite ısısının palpasyonu $(\chi 2=11,961 ; p=0.035)$, kas gücü değerlendirmesi $(\chi 2=21,358 ; p=0.001)$, eklem hareketlerinin inspeksiyonu $(\chi 2=22,878 ; p=0.000)$ ve glaskow koma ölçeğini kullanma $(\chi 2=25,932 ; \quad p=0.000)$ becerilerini öğrencilere göre daha fazla yaptıkları saptanmıştır. Öğrencilerin ise göz değerlendirmesi ( $\chi 2=17,866 ; p=0.003)$, konuşma değerlendirmesi $(\chi 2=13,147 ; p=0.022)$, omurga inspeksiyonu $(\chi 2=29,852 ; p=0.000)$, meme inspeksiyonu $(\chi 2=23,931 ; p=0.000)$, boyut ve simetri açısından kas ve ekstremitelerin inspeksiyonu $(\chi 2=23,396 ; p=0.000)$, hassasiyet yönünden ekstremite palpasyonu $(\chi 2=24,852$; $\mathrm{p}=0.000)$, kalp seslerinin oskültasyonu $(\chi 2=40,859$; $p=0.000)$, akciğer seslerinin oskültasyonu $(\chi 2=21,891$; $p=0.001)$, abdomen inspeksiyonu $\left(\chi^{2}=13,838 ; p=0.017\right)$, hassasiyet ve distansiyon yönünden abdomen palpasyonu ( $\chi 2=11,473 ; \quad p=0.043)$, bağırsak seslerinin oskültasyonu $(\chi 2=16,442 ; \quad p=0.006)$, kapiller dolum palpasyon ve inspeksiyonu ( $\chi 2=18,872 ; p=0.002)$, gaitanın incelenmesi ve inspeksiyonu $(\chi 2=12,537 ; p=0.028)$, yaraların inspeksiyonu $(x 2=16,474 ; p=0.006)$ ve yürüyüşün değerlendirilmesi $(x 2=17,891 ; p=0.003)$ becerilerini hemşirelere göre daha fazla yaptıkları belirlenmiştir.

\section{TARTIŞMA}

Hemşirenin hastayla karşılaştığı ilk andan itibaren eksiksiz ve objektif veri toplaması, hemşirelik süreci için oldukça önemlidir ${ }^{18,19}$. Hemşireler veri toplarken ve bakımı yönetirken fiziksel değerlendirme becerilerini etkin bir şekilde kullanmak durumundadır ${ }^{19,20}$. Hemşirelerin ve hemşirelik öğrencilerinin fiziksel değerlendirme becerilerini kullanma durumlarını belirlemek amacıyla yapılan bu araştırmada, hemşirelerin büyük kısmının fiziksel değerlendirme becerilerini bildiği ve bu becerileri kullandığı belirlenmiştir. Çevik ve ark. (2018) tarafından yapılan araştırmada da, hemşirelerin fiziksel değerlendirme becerileri konusunda yeterli bilgi sahibi olduğu ve bu becerilerini kullandığı belirtilmiştir ${ }^{17}$. Araştırmamızda hemşireler fiziksel değerlendirme konusunda yeterli bilgi sahibi olsa bile bunu uygulamaya aktarma konusunda sorun yaşadıklarını, klinik iş yüklerinin fazla olması nedeniyle fiziksel değerlendirmeye yeterli zaman ayıramadıklarını belirtmişlerdir. Öğrencilerin ise büyük kısmının lisans eğitiminde fiziksel değerlendirme dersi aldığı ve yarısından fazlasının fiziksel değerlendirme becerilerini klinik uygulamada kullandığı belirlenmiştir. Bu bulgu literatürdeki araştırma sonuçlarıyla da benzerdir ${ }^{12,13}$. Hemşirelik öğrencilerinin fiziksel değerlendirme becerileriyle ilgili bilgilerinin yeni ve güncel olması, bilgilerini uygulamaya aktarmak konusunda daha istekli olmaları, klinik uygulamada fiziksel değerlendirme becerilerini daha fazla kullanmalarını sağlamaktadır. Hemşirelik eğitiminde yer verilen fiziksel değerlendirme becerileri, hasta bakım kalitesini olumlu yönde etkilemektedir ${ }^{10,21}$.

Araştırmamızda hemşireler fiziksel değerlendirme becerilerini uygulamada karşılaştıkları veya algıladıkları başlıca engelleri; iş yükü, zaman yetersizliği, yeterli bilgi ve beceriye sahip olmadığını düşünmek, fiziksel değerlendirme becerilerini uygulamayı hemşirenin görevi olarak düşünmemek olarak bildirmiştir. Literatürde de benzer şekilde hemşirelerin fiziksel değerlendirme becerilerini uygulamada karşılaştıkları engeller; bilgi eksikliği, hemşirelerin ağır iş yükü3,16, fiziksel değerlendirmenin hekimin görevi olduğu görüşü, hasta sayısının fazla olması, hemşire sayısının yetersiz olması ${ }^{16}$, zaman yetmezliği ${ }^{3,21}$ olarak belirtilmiştir.

Araştırmaya katılan öğrencilerin yarısından fazlasının fiziksel değerlendirme becerilerini klinikte uyguladıkları saptanmıştır. Öğrenciler fiziksel değerlendirme becerilerini uygulamaya ilişkin karşılaştıkları veya algıladıkları başlıca engelleri ise öğretim elemanının fiziksel değerlendirme becerileri uygulamalarını desteklememesi, hastaların fiziksel değerlendirme becerilerinin yapılmasını kabul etmemesi, hekimler tarafından öğrencilerin fiziksel değerlendirme becerilerinin uygulanmasının desteklenmemesi olarak bildirmiştir. Bu sonuçlarla paralel olarak literatürde de öğrencilerin fiziksel değerlendirme becerilerini uygulamada karşılaştıkları engeller; becerileri uygulayacak uygun ortam olmaması, kendilerini geliştirme fırsatı bulamamaları ${ }^{12}$, zaman yetersizliği ${ }^{14}$, hemşirelik eğitim programlarının heterojenliği ${ }^{22}$, güven eksikliği, fiziksel değerlendirmeyi doğru yapamama endişesi ve hasta bakımı üzerinde kendisinin bir katkısının olmadığını düşünmesidir ${ }^{13,23}$. Bu bulgular, hemşirelik lisans eğitiminde yer alan temel hemşirelik derslerinde fiziksel değerlendirmeye yeterince önem verilmediğini düşündürmektedir. Üstelik fiziksel değerlendirme dersinin çoğu zaman seçmeli olması veya müfredatta ders olarak yer almaması, dersin pratik uygulamasını yapacak ekipmanlara veya laboratuvar imkanlarına her okulun sahip olmaması da önemli bir sınırlılıktır.

Fiziksel değerlendirmenin uygulamasında yeterli ve kaliteli eğitimin ne kadar önemli olduğu, bu araştırmanın sonuçlarına da yansımıştır. Fiziksel değerlendirme dersini alan öğrencilerin, dersi almayanlara göre fiziksel değerlendirme becerilerini daha fazla kullandıkları belirlenmiştir. $\mathrm{Bu}$ bağlamda, öğrencilerin fiziksel değerlendirmeyle ilgili ayrıntılı ders almaları, bu becerilerin uygulamaya aktarılmasını kolaylaştırabilmektedir. Hemşirelerin ise eğitim seviyesi yükseldikçe fiziksel değerlendirme becerilerini kullanma durumlarının arttığı tespit edilmiştir.

Araştırmada klinik deneyim süresi az olan hemşirelerin, klinik deneyim süresi daha fazla olanlara göre fiziksel değerlendirme becerilerini daha çok kullandıkları saptanmıştır. $\mathrm{Bu}$ durumun fiziksel değerlendirme 
becerilerinin kazandırıldığı derslere son yıllarda daha çok önem verilmesinden kaynaklandığı düşünülmektedir. Cicolini ve ark. (2015) tarafından yapılan araştırmada, yeni mezun hemşireler ve deneyimli hemşirelerin gerçekleştirdiği rutin becerilerin, birkaç teknik dışında, niteliğinde ve niceliğinde anlamlı fark bulunmadığı bildirilmiştir ${ }^{22}$.

Bu araştırmada dahili, cerrahi ve yoğun bakım kliniklerinde çalışan hemşirelerin diğer birimlerde çalışan hemşirelere göre birçok beceriyi daha fazla kullandıkları belirlenmiştir. Cicolini ve ark. (2015) tarafından yapılan araştırmada da benzer şekilde yoğun bakımda ve bakım evlerinde çalışan hemşirelerin fiziksel değerlendirme becerilerini daha çok kullandıkları saptanmıştır22. Dolayısıyla hastalara uzun süreli bakım ve takip gereken kliniklerde çalışan hemşirelerin fiziksel değerlendirme becerilerini kullanmayla ilgili deneyimlerinin daha fazla olduğu söylenebilir.

Araştırmamızda hemşirelerin ve öğrencilerin klinik ortamda en sık kullandığı fiziksel değerlendirme becerileri birbirinden farklıdır. Koç ve Sağlam (2012) tarafından yapılan bir araştırmada hemşirelerin en sık kullandıkları fiziksel değerlendirme becerileri yaşamsal bulguların ölçülmesi, periferik nabız değerlendirilmesi, bilinç değerlendirmesidir. Uygulama yapmadıkları beceriler ise tiroid bezleri, kraniyal sinirlerin ve derin tendon reflekslerinin değerlendirilmesidir ${ }^{16}$. Cicolini ve ark. (2015) tarafından yapılan araştırmada her muayenede en çok uygulanan beceriler; ekstremitelerin, cilt lezyonlarının ve genel cilt renginin inspeksiyonu olarak bildirilmiştir ${ }^{22}$. Douglas ve ark. (2015) tarafından yapılan araştırmada ise hemşirelik öğrencileri 126 beceriden ortalama olarak yalnızca beş tanesini her uygulamalarında yaptıklarını ve becerilerin büyük kısmının klinik ortamlarda hiç uygulanmadığını belirtmişlerdir ${ }^{12}$. Aynı araştırmada öğrencilerin yaptıkları fiziksel değerlendirmenin genel değerlendirme ve gözlemden ibaret olduğu ve palpasyan, perküsyon, oskültasyon becerilerini kullanmadıkları saptanmıştır.

Araştırmamızda hemşirelerin inspeksiyon yöntemini daha çok kullandıkları belirlenmiştir. İnspeksiyonun daha fazla kullanılma nedeni, daha az beceri gerektirmesi ve daha kolay öğrenilip uygulanması olabilir. Literatürde de kapsamlı fiziksel değerlendirme becerilerinin hepsinin günlük yapılmadığı, hemşirelerin fiziksel değerlendirme becerilerini uygularken kendini genel olarak rahat hissetmediği bildirilmektedir ${ }^{10,21,24}$. Araştırmamızda hemşirelerin omurga muayenesini ve bazı oskültasyon uygulamalarını (kalp, abdomen ve akciğer sesleri) yapmadığı saptanmıştır. Bunun nedeni ise üst düzey yetkinlik gerektirdiği düşünülerek hemşirelik uygulamasının bir parçası olarak görülmemesi ve daha sık hekimler tarafından uygulanması gerektiğinin düşünülmesi olabilir. Literatürde pek çok araştırmada hemşirelerin fiziksel değerlendirme becerilerini düzenli olarak kullanma konusunda yetersiz oldukları belirtilmiştir ${ }^{10,11,21,24}$. Öğrenciler açısından baktığımızda ise inspeksiyon yönteminin yanı sıra bazı oskültasyon (kalp, akciğer, bağırsak sesleri) becerilerinin hemşirelere göre daha fazla yapıldığı görülmektedir. Bunun nedeni ise öğrencilerin yeni edindikleri becerileri uygulamaya aktarma konusunda daha istekli olmaları olabilir. Literatürde hemşirelik öğrencilerinin fiziksel değerlendirme dersinde öğrendikleri becerileri klinikte eksik uyguladıkları ifade edilmiştir ${ }^{12,13,25}$. Dolayısıyla hemşirelerin ve öğrencilerin fiziksel değerlendirme becerilerini uygulamada karşılaştığı pek çok engel, kliniklerde yeterli uygulama yapmamalarına yol açabilmektedir.

\section{SONUÇ ve ÖNERILER}

Hemşirelerin ve hemşirelik öğrencilerinin fiziksel değerlendirme becerilerini kullanma durumlarını belirlemek amacıyla yapılan bu araştırmada, hemşirelerin ve öğrencilerin çoğunun fiziksel değerlendirme yöntemlerini bilmesine karşın, iş yükü, yeterli zaman bulamama, yeterli bilgi ve beceriye sahip olmadığını düşünme gibi bazı nedenlerden dolayı fiziksel değerlendirme becerilerini daha az kullandıkları sonucuna ulaşılmıştır. Hem öğrencilerin hem de hemşirelerin fiziksel değerlendirme becerilerinden en çok inspeksiyonu kullandığı belirlenmiştir. Hemşirelerin iş yükünün azaltılması ve hizmet içi eğitim programlarında yeterli desteğin sağlanması ile hemşirenin özerkliğinin ve profesyonelliğinin güçleneceği, sistematik bakımın kolaylaşacağı, hemşire-hasta güven ilişkisinin desteklenerek daha kaliteli bakım sağlanacağı düşünülmektedir.

Fiziksel değerlendirme yapılmasına ilişkin karşılaşılan veya algılanan engellerin ortadan kaldırılmasında; hemşirelik lisans eğitimine fiziksel değerlendirme dersinin ve/veya konusunun eklenmesi, hemşirenin rol ve sorumluluklarının ayrıntılı anlatılması, hemşirelere konuyla ilişkili hizmet içi eğitimler planlaması, hemşirelerin ve hemşirelik öğrencilerinin fiziksel değerlendirme becerilerini kullanmalarının desteklenmesi ve fiziksel değerlendirmeye yeterli zaman ayrılabilmesi için çalışan hemşire sayısının artırılması gibi faktörlerin önemli olduğu düşünülmektedir.

Etik Kurul Onayı (Kurul adı, tarih ve sayı no): Gazi Üniversitesi Etik Komisyonu, 17.10.2017- E.147531

Çıkar Çatışması: Bildirilmemiştir.

Finansal Destek: Yoktur.

Katılımcı Onamı: Katılımcılardan sözlü ve yazılı onam alınmıştır.

\section{Yazar katkıları}

Araştırma dizaynı: NÇ, ND, BCE

Veri toplama: $\mathrm{NC}, \mathrm{ND}, \mathrm{BCE}, \mathrm{GE}, \mathrm{EE}$

Literatür araştırması: NÇ, ND, BCE

Makale yazımı: NÇ, ND, BCE, NCSÇ, ANK, GE, EE 
Teşekkür: Araştırmamıza katılmaya gönüllü olan hemşire ve hemşirelik öğrencilerine teşekkür ederiz.

*Bu çalışma, 29 Kasım - 1 Aralık 2018 tarihlerinde Ankara'da gerçekleştirilen 3. Uluslararası Sağlık Bilimleri kongresinde sözel bildiri olarak sunulmuştur.

Ethics Committee Approval: Gazi University Ethics Committee, 17.10.2017- E.147531

Conflict of Interest: Not reported.

Funding: None.

Exhibitor Consent: Verbal and informed consent was obtained from the participants.

Author contributions

Study design: NÇ, ND, BCE

Data collection: NÇ, ND, BCE, GE, EE

Literature search: NÇ, ND, BCE

Drafting manuscript: NÇ, ND, BCE, NCSÇ, ANK, GE, EE

Acknowledgement: We would like to thank all the nurses and nursing students who volunteered to participate to the study.

* This study was presented as an oral presentation at the 3rd International Health Sciences Congress held in Ankara on 29 November - 1 December 2018.

\section{KAYNAKLAR}

1. Anderson B, Nix E, Norman B, McPike HD. An evidence based approach to undergraduate physical assessment practicum course development. Nurse Educ Pract. 2014;14: 242-6.

2. Eyüboğlu G, Çalışkan N. Hemşirelerin fiziksel muayene becerilerini kullanmalarındaki engeller. Gümüşhane Üniversitesi Sağlık Bilimleri Dergisi. 2019;8(2):57-61.

3. Fennessey A, Wittmann Price RA. Physical assessment: A continuing need for clarification. Nursing Forum. 2011;46(1):45-50.

4. Görgülü RS. Hemşireler için fiziksel muayene yöntemleri. 1. Baskı. İstanbul: İstanbul Medikal Yayıncilık; 2014.

5. Lynn P. Taylor's Clinical Nursing Skills: A Nursing Process Approach. 3rd ed. Philadelphia: Lippincott Williams and Wilkins; 2011.

6. Potter PA, Perry AG, Stockert P, Hall A. Fundamentals of Nursing. 9th ed. Canada: Elsevier Health Sciences; 2016.

7. Jarvis C. Physical Examination and Health Assessment. 8th ed. E-Book: Elsevier Health Sciences; 2019.

8. Ellen M, Estes Z. Health Assesment and Physical Examination. 5th ed. USA: Cengage Learning; 2013.

9. Taylor L, Lillis C, Lemone P. Fundamentals of Nursing: The Art and Science of Nursing. 7th ed. Philadelphia: Lippincott Williams and Wilkins; 2010.

10. Giddens JF. A survey of physical assessment techniques performed by RNs: Lessons for nursing education. J Nurs Educ. 2007;46(2):83-7.
11. Osborne S, Douglas C, Reid C, Jones L, Gardner G. The primacy of vital signs acute care nurses' and midwives' use of physical assessment skills: A cross sectional study. Int J Nurs Stud. 2015;52:951-962.

12. Douglas C, Windsor C, Lewis P. Too much knowledge for a nurse? Use of physical assessment by final-semester nursing students. Nurs Health Sci. 2015;17:492-9.

13. Alamri MS, Almazan JU. Barriers of physical assessment skills among nursing students in Arab Peninsula. Int J Health Sci. 2018;12(3):58-66.

14. Giddens JF, Eddy L. A survey of physical examination skills taught in undergraduate nursing programs: Are we teaching too much? J Nurs Educ. 2009;48(10):24-9.

15. Aydın D, Dörtbudak Z. Hemşirelerin hasta tanılama kapsamında fizik muayene bilgi ve uygulamaları -pilot çalışma. HEAD. 2004;1(1):2933.

16. Koç Z, Sağlam Z. Determination of physical assessment skills used by nurses in Turkey. HealthMed. 2012;6(3):765-73.

17. Çevik B, Uğurlu Z, Akyüz E, Kav S, Ersayın A. Hemşirelerin fiziksel değerlendirme becerileri ve uygulamaya ilişkin görüşleri. Hacettepe Üniversitesi Hemşirelik Fakültesi Dergisi. 2018;5(1):39-48.

18. Potter P, Perry AG, Stockert PA, Hall AM. Fundamentals of Nursing. 8th ed. Canada: Elsevier Inc; 2013.

19. Craven RF, Hirnle JC, Jensen S. Fundamentals of Nursing: Human Health and Function. 7th. ed. Philadelphia: Lippincott Williams and Wilkins; 2013.

20. Ramont RP, Niedringhaus DM. Fundamental Nursing Care. 2th ed. New Jersey: Pearson; 2007.

21. Birks M, Cant R, James A, Chung C, Davis J. The use of physical assessment skills by registered nurses in Australia: Issues for nursing education. Collegian. 2013;20:27-33.

22. Cicolini $G$, Tomietto $M$, Simonetti $V$, Comparcini $D$, Flacco MA, Carvello M, et al. Physical assessment techniques performed by Italian registered nurses: A quantitative survey. J Clin Nurs. 2015;24:3700-6.

23. Sharif $F$, Masoumi $S$. A qualitative study of nursing student experiences of clinical practice. BMC Nurs. 2005;4:6.

24. Giddens J. Comparing the frequency of physical examination techniques performed by associate and baccalaureate degree prepared nurses in clinical practice: does education make a difference. J Nurs Educ. 2006;45:136-9.

25. Wilson SF, Giddens JF. Health Assessment for Nursing Practice. 6th ed. E-Book: Elsevier Health Sciences; 2016 